\title{
Spatial variations in fish assemblage structure in a southeastern Brazilian reservoir
}

\author{
B. O. Sanches ${ }^{a}$, R. M. Hughes ${ }^{b}$, D. R. Macedo ${ }^{c}$, M. Callisto ${ }^{d}$ and G. B. Santos ${ }^{a *}$ \\ aPrograma de Pós-graduação em Zoologia de Vertebrados, Pontifícia Universidade Católica de Minas Gerais - PUC Minas, \\ Avenida Dom José Gaspar, 500, CEP 30535-610, Belo Horizonte, MG, Brazil \\ ${ }^{b}$ Department of Fisheries \& Wildlife, Amnis Opes Institute, Oregon State University, \\ 200 SW 35th Street, Corvallis, OR 97333, USA \\ 'Instituto Brasileiro de Geografia e Estatística - IBGE, Rua Oliveira, 523, \\ CEP 30310-150, Belo Horizonte, MG, Brazil \\ dDepartamento de Biologia Geral, Universidade Federal de Minas Gerais - UFMG, \\ CP 486, CEP 30161-970, Belo Horizonte, MG, Brazil \\ *e-mail: gilmarsantos4@hotmail.com
}

Received: August 14, 2014 - Accepted: October 30, 2014 - Distributed: February 29, 2016

(With 3 figures)

\begin{abstract}
We assessed the fish assemblage structure and composition of Nova Ponte Reservoir (Araguari River, Upper Paraná Basin, Brazil). We observed significant differences in abundance $(p=0.0003)$, richness $(p=0.0005)$ and diversity $(\mathrm{p}=0.02)$ between lacustrine and riverine zones of the reservoir. Nine species were significantly more abundant in the riverine region: Astyanax altiparanae, Astyanax gr. fasciatus, Galeocharax knerii, Hoplias intermedius, Hypostomus sp., Leporinus friderici, Leporinus obtusidens, Pimelodus maculatus and Schizodon nasutus. The results indicated a longitudinal gradient in the composition and abundance of fishes in Nova Ponte Reservoir, reinforcing the importance of freely flowing riverine reaches for conserving native neotropical ichthyofauna and reflecting the strong adaptation of these species to riverine systems.
\end{abstract}

Keywords: fish community, Upper Paraná River Basin, spatial gradient.

\section{Variações espaciais na estrutura das assembléias de peixes em um reservatório do sudeste do Brasil}

\section{Resumo}

Este estudo avaliou a assembléia de peixes do reservatório de Nova Ponte (rio Araguari, bacia do Alto Paraná, Brasil), em termos de estrutura e composição. Foram observadas diferenças significativas na abundância $(p=0.0003)$, riqueza $(\mathrm{p}=0.0005)$ e diversidade $(\mathrm{p}=0.02)$ entre as zonas lacustres e fluviais do reservatório. Nove espécies foram mais abundantes na região fluvial: Astyanax altiparanae, Astyanax gr. fasciatus, Galeocharax knerii, Hoplias intermedius, Hypostomus sp., Leporinus friderici, Leporinus obtusidens, Pimelodus maculatus and Schizodon nasutus. Os resultados indicaram a existência de um gradiente longitudinal na composição e abundância de peixes no reservatório de Nova Ponte. Estes padrões reforçam a importância de trechos fluviais livres de barramentos para a conservação da ictiofauna neotropical nativa e refletem a forte adaptação dessas espécies aos sistemas fluviais.

Palavras-chave: comunidade de peixes, Bacia do Alto Rio Paraná, gradiente espacial.

\section{Introduction}

In recent years, the construction of large dams, mainly for hydroelectric generation, has become one of the most frequent anthropogenic interventions in Brazilian rivers. Because of changes in flow regimes, sediment and nutrient transport, energy flow, and biota, a dam interrupts and changes important ecological processes (Benedito-Cecilio and Agostinho, 2000; Poff et al., 2007). The fish assemblages present in reservoirs are a result of the restructuring of those assemblages that occupied the river segment before damming (Araújo-Lima et al., 1995). This process is marked by the extirpation of some species, reduced abundances of many species (Gehrke and Harris, 2001; Gomes and Miranda, 2001; Gehrke et al., 2002), and proliferation of other species (Pelicice and Agostinho, 2009). It is expected that species with greater plasticity in their feeding and spawning requirements are among the 
dominant ones (Gehrke and Harris, 2001). Population depletions occur mainly among species that are migratory, long-lived, and have low reproductive potential (Agostinho and Gomes, 2006).

The longitudinal compartmentalization of reservoirs divides them into well-characterized zones, where the water mass is often divided into lacustrine (LZ), transitional, and riverine (RZ) zones (Thornton, 1990; Terra and Araujo, 2011). The RZ is characterized by greater water flow, shallower depths (Thornton, 1990), and more nutrient availability (Oliveira et al., 2003). Some authors emphasize that reservoir tributaries and riverine regions act as refuges for native species (Oliveira et al., 2005; Gao et al., 2010). This fact is reinforced by the tendency of native species to colonize sites with riverine features (Agostinho et al., 2007) and by the greater diversity and proportion of rare species found in tributaries and RZ (Oliveira et al., 2003).

Several studies have recognized the importance of remote sensing in identifying elements in the water column such as suspended sediment and chlorophyll (Harrington Junior et al., 1992; Hedger et al., 2002; Assireu et al., 2011). In reservoirs, those elements are good indicators of sediment and nutrient dynamics. In the RZ, the trend is for a high load of suspended sediment and photosynthetic algae (Wetzel, 2001). In this sense, data from satellite images combined with in situ data are very useful for assessing compartmentalization in seasonally variable tropical reservoirs (Assireu et al., 2011).
We assessed fish assemblage features and ecological parameters in a Brazilian reservoir to verify spatial patterns related to compartmentalization (division into LZ and RZ). Correlations between turbidity and pheophytin and biological parameters were examined to assess the influences of key limnological variables on fish assemblages. We hypothesized that there would be a nonrandom pattern in fish abundance and assemblage structure and composition between lacustrine and riverine zones.

\section{Material and Methods}

\subsection{Study area and site selection}

Prior to artificial fragmentation by a series of dams along the hydrographic system, the Araguari River was an important migration route for native fish. Presently, the Araguari River main channel is modified by four large (installed capacity: 210 to $510 \mathrm{MW}$ ) and two small (installed capacity: 6.2 and $23 \mathrm{MW}$ ) hydropower plants. Its largest tributary, the Quebra-Anzol River, still features a freely flowing segment that is about $70 \mathrm{~km}$ long (Vono, 2002), which is one of the few remaining segments for recruitment of fish larvae and juveniles in this region of the basin. The Nova Ponte Hydroelectric Plant is located in the middle section of the Araguari River (Figure 1) and began operation in 1994. Most of Nova Ponte Reservoir ( $\left.19^{\circ} 07^{\prime} 41.6^{\prime \prime} \mathrm{S}, 47^{\circ} 41^{\prime} 22.8^{\prime \prime} \mathrm{W}\right)$ is formed by the Quebra-Anzol River (Vono, 2002). The reservoir is $120 \mathrm{~m}$ deep near the dam, $115 \mathrm{~km}$ long, has a volume

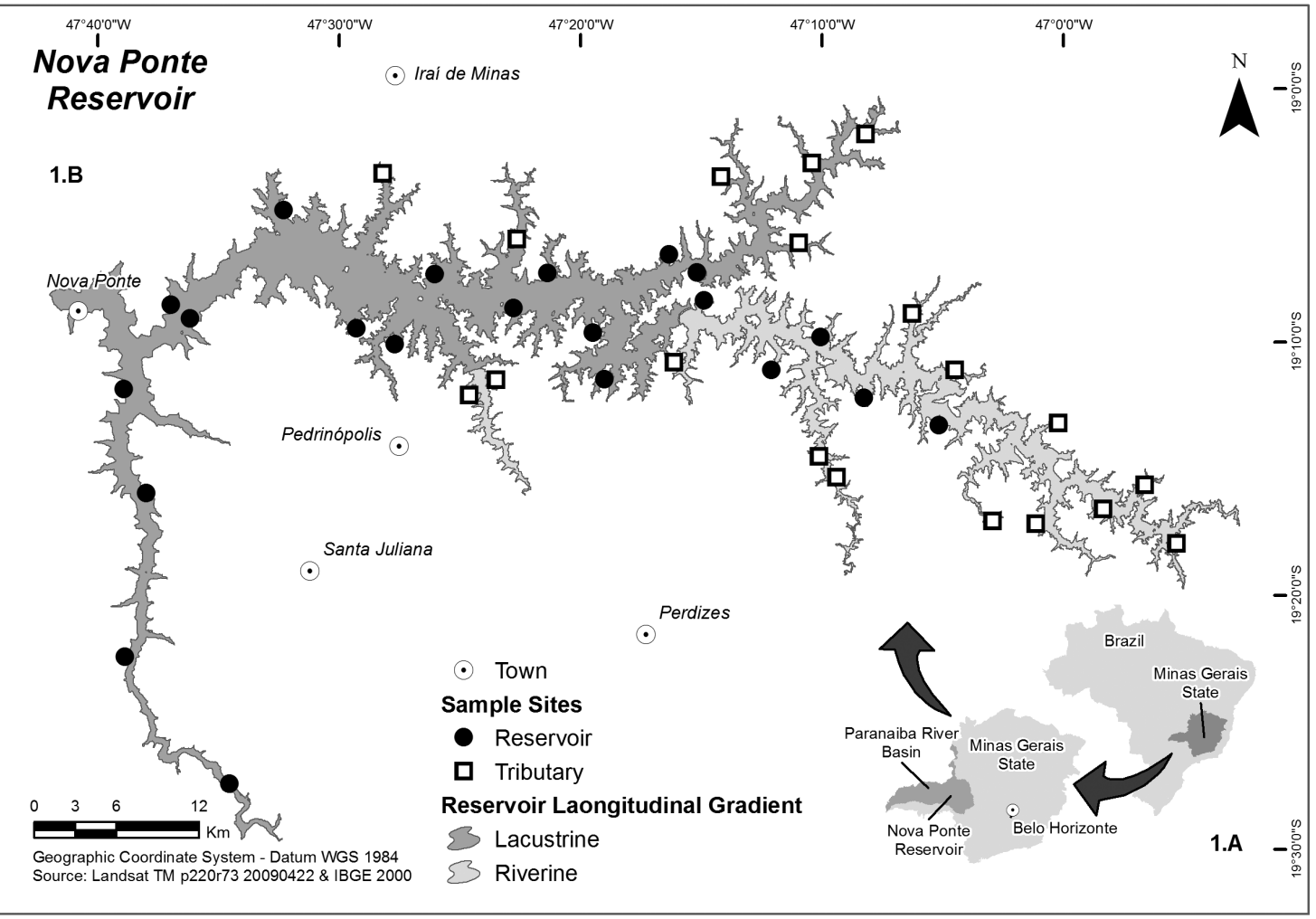

Figure 1. Nova Ponte Reservoir lacustrine and riverine zones and locations of tributary and reservoir sites. 
12.8 billion $\mathrm{m}^{3}$, and is oligotrophic and stratified during most of the year (Vono, 2002).

We selected sampling sites by dividing the reservoir perimeter into 40 equal sections from a random first point defined according to the concept of a spatially balanced sample network (Stevens and Olsen, 2004) adapted for large reservoirs (Macedo et al., 2012). Each site was located at the beginning of each section and each site was $200 \mathrm{~m}$ long. We sampled the sites at the end of the rainy season in 2010.

We divided the reservoir into two zones in two steps. First, we used classified Landsat 5 TM images taken during our field sampling period (April 2010) to distinguish RZ and LZ visually. After acquisition and image geo-referencing, we performed atmospheric correction by the dark object subtraction method (Chavez Junior, 1988). We used the green ( 0.52 to $0.60 \mathrm{~mm}$ ), red (from 0.63 to $0.69 \mathrm{~mm}$ ), and near infrared spectral bands ( 0.76 to $0.90 \mathrm{~mm}$ ), which aid proper detection of algae and suspended sediment concentrations (Jensen, 2006). We classified reservoir zones through use of the maximum likelihood method, using areas of the reservoir close to the dam (to characterize the LZ) and major tributary mouths (to characterize the RZ) as training areas. We expected that the RZ would have higher concentrations of suspended solids (Wetzel, 2001) and consequently higher turbidity than the LZ. Although turbidity was higher in the RZ of Nova Ponte reservoir, the decrease in light penetration did not preclude primary production. In addition, we expected abundant algae in this zone because light was sufficient and nutrients were abundant compared to the LZ (Wetzel, 2001). In our second step to classify reservoir zones, we used water samples to test whether there were significant differences in limnological parameters between those previously classified zones. We used in situ measurements of suspended solids (measured by turbidity) and algae (measured by pheophytin) concentrations. After finding the non-normality of these parameters using the Kolmogorov-Smirnov test, we employed a Mann-Whitney test corrected by Bonferroni criteria (Zar, 2009) to test differences between zones related to these parameters. At a smaller spatial scale, we also classified sites as tributary or reservoir. Tributary sites were located at or very near the mouths of small or large tributaries, and reservoir sites were distant from tributaries. This secondary site classification yielded tributary sites in the LZ and reservoir sites in the RZ (Figure 1).

\subsection{Fish sampling}

We collected fish through use of gill nets with mesh sizes between 3 and $16 \mathrm{~cm}$ (distance between opposite knots), heights ranging between 1.6 and 1.8 meters, and lengths of 20 meters. At each sampling site, we placed a set of five pairs of nets comprising the following mesh sizes: 3-8, 4-10, 5-12, 6-14 and 7-16. Each pair was placed at a distance of $40 \mathrm{~m}$ from the other at an angle of approximately 45 degrees from the reservoir shore. The nets were set in the evening and removed the following morning, with a total exposure time of approximately $15 \mathrm{~h}$. The specimens collected were fixed in $10 \%$ formalin and identified in the laboratory through use of a taxonomic key (Graça and Pavanelli, 2007). We considered as non-native species that did not originally belong to this part of the Upper Paraná Basin (according to Graça and Pavanelli, 2007). Individuals difficult to identify and voucher specimens were deposited in the ichthyological collection of the Universidade Estadual Paulista, São José do Rio Preto (São Paulo).

\subsection{Data analyses}

Because sampling effort was constant, we used the total number of collected specimens to compare sampling sites. We used the total number of species as an indicator of taxonomic richness, and estimated Shannon diversity (H') and evenness (Heip index) as proposed by Magurran (2011).

To assess differences between the LZ and RZ, we applied the Mann-Whitney test (Zar, 2009) on the medians of 1) the abundance, richness, diversity, and evenness and 2) the abundance of selected species (most abundant, migratory, rheophilic) in each site. We also calculated Spearman correlations between assemblage variables and turbidity and pheophytin to assess the biological effects of single environmental variables. Similarly, to verify the influence of tributaries on ecological parameters, we also applied the Mann-Whitney test (Zar, 2009) to assess differences in the medians of abundance, total richness, diversity, and evenness between tributary versus reservoir sites.

We also assessed the difference in assemblage composition between zones, through use of nonmetric multidimensional scaling (NMDS). We performed NMDS on a Bray-Curtis similarity matrix built from species relative abundance data transformed by $\log (\mathrm{x}+1)$ after excluding species that occurred at fewer than $5 \%$ of the points (Legendre and Legendre, 1998; McCune et al., 2002). To validate the analysis, only stress values near 0.2 (Legendre and Legendre, 1998) were admitted. To test the significance of groups, we performed an ANOVA similarity (one way ANOSIM) test (Clarke and Warwick, 2001).

To evaluate the influence of site location (LZ or RZ) on abundance, we applied a Mantel test (Mantel, 1967). We compared two matrices: a similarity matrix, constructed from the captures from each site using the Bray-Curtis similarity index and a dissimilarity matrix, which had zeros for pairs of stations located in the same zone and 1 for pairs of sites located in distinct zones of the reservoir (Oliveira et al., 2004).

The significance level accepted for all analyses was 0.05 , and the analyses were conducted with Statistica 8.0 (StatSoft, 2007), Estimate S (Colwell, 2009), Primer 6.1.13 (Anderson et al., 2008), and R 2.15.1 (R Core Team, 2012) software.

\section{Results}

The LZ had significantly less turbidity $(\mathrm{U}=51$, $\mathrm{p}=0.00002)$ and pheophytin $(\mathrm{U}=114, \mathrm{p}=0.021)$ compared to the RZ (Figure 2). During the sampling period, we captured 2463 specimens, distributed among 3 orders, 
12 families and 29 species (Appendix A). Three were migratory species: Leporinus obtusidens (Valenciennes, 1837), Salminus hilarii Valenciennes, 1850, Prochilodus lineatus (Valenciennes, 1836) and five were alien species: Oreochromis niloticus (Linnaeus, 1758), Tilapia rendalli (Boulenger, 1897), Pygocentrus nattereri Kner, 1858, Cichla piquiti Kullander e Ferreira, 2006, Metynnis gr. lippincottianus (Cope, 1870). The five most abundant species together accounted for $72.8 \%$ of the catch: Iheringichthys labrosus (Lütken, 1874), Pimelodus cf. maculatus Lacepède, 1803, Astyanax gr. fasciatus (Cuvier, 1829), Schizodon nasutus Kner, 1858, Galeocharax knerii (Steindachner, 1879). The introduced species P. nattereri and $C$. piquiti were among the eight most frequently captured and were present respectively in 36 and 34 of the 40 sampling sites, whereas migratory species totaled only $2.2 \%$ of the fish captured.

We observed significant differences between reservoir zones in assemblage composition (Figure 3), abundance, richness, and diversity - but not evenness (Table 1). From the 13 most abundant species, only I. labrosus, P. nattereri, and $C$. piquiti did not differ significantly between $\mathrm{LZ}$ and RZ. Other species were significantly more abundant in the RZ: A. gr. fasciatus (Cuvier, 1819), Astyanax altiparanae Garutti and Britski, 2000, Galeocharax knerii (Steindachner, 1879), Hoplias gr. malabaricus (Bloch, 1794), Hypostomus sp., L. obtusidens, Leporinus friderici (Bloch, 1794), P. maculatus and S. nasutus (Table 2). However, Hoplias intermedius Oyakawa and Mattox, 2009, was the only species that was more abundant in the LZ.

Abundance and richness were significantly higher at the tributary sites than at sites in the main body of the reservoir; however, there was no significant difference in diversity or evenness (Table 1). Spearman correlations between turbidity and richness $(0.63)$, diversity $(0.52)$ and abundance $(0.55)$ were significant, but not between evenness and turbidity (0.02). Correlations between pheophytin and assemblage variables were not significant: richness $(0.26)$, diversity (0.22), abundance (0.25), and evenness (0.003).

Despite the significant difference in abundance and species composition between zones, there was overlap between them as expected (ANOSIM: $\mathrm{R}=0.27, \mathrm{p}=0.0003$ ). There was a positive correlation between the similarity matrix constructed from the abundance data and the dissimilarity matrix based on site locations in different zones (Mantel: $\mathrm{R}=0.18, \mathrm{p}=0.0004)$. This indicates non-random patterns of capture and the existence of a longitudinal gradient in abundance and species composition.

\section{Discussion}

The dominance of so few species in Nova Ponte Reservoir seemed remarkable; however, this has been observed in other reservoirs, which are new environments and have unstable assemblages, often greatly simplified

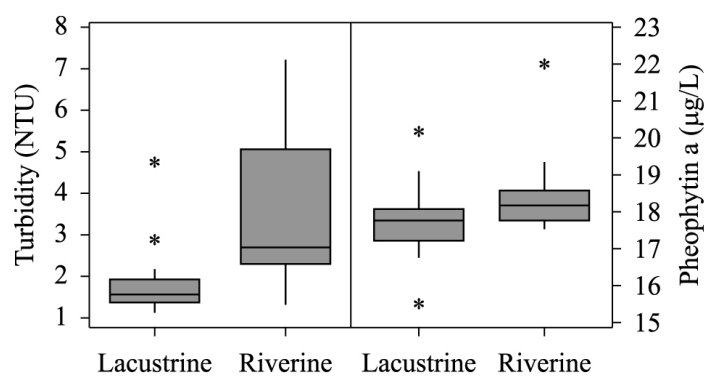

Figure 2. Turbidity (left) and pheophytin $a$ (right) of Nova Ponte Reservoir zones.

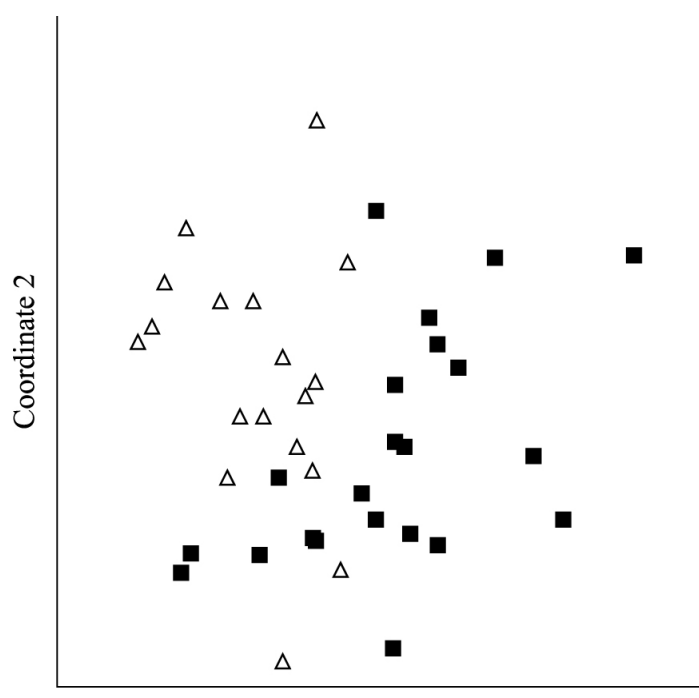

Coordinate 1

Figure 3. Fish assemblage composition as represented by NMDS based on Bray Curtis analysis of proportional abundance data. Stress $=0.2$. (riverine sites $=$ triangles, lacustrine sites $=$ squares).

Table 1. Results of the Mann-Whitney U-test (values in bold are significant), for differences in abundance, richness, evenness, and diversity (Shannon) between tributary (TR) MB) sites and between lacustrine (LA) and riverine (RI) zones (and main body of the reservoir (see Figure 1 for site and zone locations).

\begin{tabular}{|c|c|c|c|c|c|c|c|c|}
\hline & \multicolumn{2}{|c|}{ Ranks sum } & \multirow{2}{*}{$\mathbf{p}$} & \multirow{2}{*}{$\mathbf{U}$} & \multicolumn{2}{|c|}{ Ranks sum } & \multirow{2}{*}{$\mathbf{p}$} & \multirow{2}{*}{$\mathbf{U}$} \\
\hline & LA & RI & & & MB & TR & & \\
\hline Abundance & 319 & 502 & 0.0003 & 66 & 329 & 491 & 0.005 & 98 \\
\hline Richness & 314 & 507 & 0.0005 & 75 & 315 & 505 & 0.001 & 152 \\
\hline Diversity & 342 & 478 & 0.02 & 89 & 383 & 437 & 0.205 & 152 \\
\hline Evenness & 492 & 329 & 0.27 & 158 & 491 & 329 & 0.1 & 139 \\
\hline
\end{tabular}


Table 2. Results of the Mann-Whitney U-test (values in bold are significant) for differences in abundances of frequently captured species between the lacustrine and riverine zones (see Figure 1 for zone locations).

\begin{tabular}{|c|c|c|c|c|}
\hline \multirow{2}{*}{ Species } & \multicolumn{2}{|c|}{ Ranks sum } & \multirow{2}{*}{$\mathbf{P}$} & \multirow{2}{*}{$\mathbf{U}$} \\
\hline & Lacustrine & Riverine & & \\
\hline Astyanax altiparanae 4 & 361.0 & 459.0 & 0.014 & 108.0 \\
\hline Astyanax gr. fasciatus ${ }^{4}$ & 358.0 & 462.0 & 0.011 & 105.0 \\
\hline Cichla piquiti $^{3,4}$ & 467.0 & 353.0 & 0.677 & 182.0 \\
\hline Galeocharax knerii ${ }^{4}$ & 376.5 & 443.5 & 0.042 & 123.5 \\
\hline Hoplias intermedius ${ }^{4}$ & 539.5 & 280.5 & 0.015 & 109.5 \\
\hline Hoplias gr. malabaricus ${ }^{4}$ & 339.0 & 481.0 & 0.002 & 86.0 \\
\hline Hypostomus sp. ${ }^{2}$ & 372.5 & 447.5 & 0.032 & 119.5 \\
\hline Iheringichthys labrosus ${ }^{4}$ & 459.5 & 360.5 & 0.819 & 189.5 \\
\hline Leporinus obtusidens ${ }^{1}$ & 346.5 & 473.5 & 0.004 & 93.5 \\
\hline Leporinus friderici $i^{4}$ & 339.0 & 481.0 & 0.002 & 86.0 \\
\hline Pimelodus cf. maculatus ${ }^{4}$ & 349.5 & 470.5 & 0.005 & 96.5 \\
\hline Pygocentrus nattereri ${ }^{3,4}$ & 436.5 & 383.5 & 0.697 & 183.5 \\
\hline Schizodon nasutus ${ }^{4}$ & 299.0 & 521.0 & 0.000 & 46.0 \\
\hline
\end{tabular}

${ }^{1}$ Migratory species. ${ }^{2}$ Rheophilic species. ${ }^{3}$ Non-native species. ${ }^{4}$ Most abundant species.

from those existing in the undammed river (Oliveira and Goulart, 2000).

The dominance of $C$. piquiti and P. nattereri at most sites and their distribution in both reservoir zones demonstrate their relatively rapid colonization success in Nova Ponte Reservoir. Both species were also found downstream in Itumbiara (Vono, 2002) and Capim Branco (Rêgo, 2008) Reservoirs. The presence of alien species is widely reported in other reservoirs located in the Upper Paraná Basin (Gomes and Miranda, 2001; Alves et al., 2007; Carvalho and Silva, 2007). Introductions and establishment of Cichla species were also mentioned (Oliveira et al., 2003; Luiz, 2010) as was the suppression of the local fish fauna (Pelicice and Agostinho, 2009). The establishment of alien fish species is a key biological mechanism for transforming native fish assemblages (Leprieur et al., 2008; Hughes and Herlihy, 2012). These changes are even more drastic in reservoirs, which are biologically simplified environments (Luiz, 2010).

The nonrandom pattern in total abundance and the greater abundance of some species in sites that were distant from the dam are consistent with the expectation that the dam alters several characteristics of fish assemblages along the river-reservoir axis (Prchalová et al., 2009; Terra et al., 2010). Irz et al. (2002) suggested that the processes that determine the fish distribution in reservoirs are a combination of what occurs in lakes and rivers, partly influenced by river continuity, and partly the result of the confinement of species in reservoirs.

Except for $H$. intermedius, all species that had significantly different catches between reservoir zones, occurred in smaller numbers in the LZ. According to Agostinho et al. (2008), environmental conditions that occur in the LZ impose a severe environmental filter. Therefore, it is expected that species adapted to lacustrine environments may colonize and become dominant, while others are locally eliminated (Regier et al., 2013). Rheophilic and migratory species, for example, tend to strongly decrease over time after the construction of dams (e.g. Oberdorff and Hughes 1992; Hughes et al., 2005).

Lotic characteristics determine the distribution of native species in reservoirs (Irz et al., 2002). In the RZ, the presence of conditions more similar to the original environment can explain the occurrence of a greater number of species, particularly those with specific requirements for migration and spawning such as L. obtusidens. Migratory species generally avoid lacustrine conditions and concentrate in riverine and transitional zones (Agostinho et al., 2007). Several authors also emphasized the importance of tributaries for the maintenance of remaining native fish populations in reservoirs (e.g. Agostinho et al., 2004; Oliveira et al., 2004). Greater abundances of fish at the confluence of tributaries can also be related to the tendency of many fish species to colonize sites with fluvial features (Agostinho et al., 2007).

The positive correlation found between turbidity and biological parameters (richness, diversity, abundance) indicates that many species select reservoir habitats most resembling the original riverine environment. Species associated with riverine systems usually require specific environmental characteristics to complete their life histories, particularly the reproduction, rearing, and refuge components, which vary seasonally with the hydrological regime, temperature, and turbidity (Agostinho et al., 2008).

The lacustrine regions of reservoirs severely restrict fish occupation because of thermal and chemical stratification, greater depth, and fewer microhabitats (Oliveira et al., 2003; Agostinho et al., 2004). Other features of reservoirs may limit species richness and influence the structure of assemblages in these environments, among them turbidity (Gido et al., 2009). Nearer to the dam the water mass has greater residence time and lower dissolved nutrient concentrations (Agostinho et al., 2008). Some of these features exist in the LZ of Nova Ponte Reservoir, which is oligotrophic and thermally stratified, has steep slopes, 
and great depth (120 m at the dam; Vono, 2002). Some authors stated that great depth is a key factor determining the spatial distribution of species (Irz et al., 2002) and Prchalová et al. (2008) reported greater abundance, biomass, and richness in shallower reservoir locations.

In the Upper Paraná Basin, the lack of species adapted to lacustrine environments could also explain the low colonization success of the LZ by most fish species (Agostinho et al., 2008; Terra et al., 2010). Likewise, a large portion of the fish fauna of the Araguari River Basin is represented by migratory or rheophilic species (Vono, 2002), which depend on riverine environments to complete their life histories.

In conclusion, our hypothesis of a nonrandom pattern in fish abundance and assemblage structure and composition was corroborated. The correlation between turbidity and richness, abundance, and diversity was also confirmed. These results reinforce the importance of riverine river segments for preserving the native Neotropical ichthyofauna and reflect the strong adaptation of these species to riverine systems.

\section{Acknowledgements}

We thank CEMIG-Programa Peixe-Vivo, CAPES, CNPq, FAPEMIG, and Fulbright Brasil for funding. Colleagues from the Federal University of Minas Gerais Benthic Ecology Laboratory, Federal University of Lavras, and Pontifical Catholic University of Minas Gerais helped with field collections and abiotic analysis. We dedicate this manuscript to Volney Vono, who helped us with the original site-scale sampling design and background information regarding Nova Ponte Reservoir, but whose untimely death precluded his sharing further insights regarding our results.

\section{References}

AGOSTINHO, A.A. and GOMES, L.C., 2006. O manejo da pesca em reservatórios do alto rio Paraná: avaliação e perspectivas. In: M.G. NOGUEIRA, H. RAOUL and A. JORCIN, eds. Ecologia de reservatórios: impactos potenciais, ações de manejo e sistemas em cascata. 2nd ed. São Carlos: Rima, pp. 24-55.

AGOSTINHO, A.A., GOMES, L.C. and PELICICE, F.M., 2007. A ictiofauna de reservatórios. In: A.A. AGOSTINHO, L.C. GOMES and F.M. PELICICE, eds. Ecologia e manejo de recursos pesqueiros em reservatórios do Brasil. Maringá: EDEUM, pp. 69-97.

AGOSTINHO, A.A., GOMES, L.C., VERÍSSIMO, S. and OKADA, E.K., 2004. Flood regime, dam regulation and fish in the Upper Paraná River: effects on assemblage attributes, reproduction and recruitment. Reviews in Fish Biology and Fisheries, vol. 14, pp. 11-19. http://dx.doi.org/10.1007/s11160-004-3551-y.

AGOSTINHO, A.A., PELICICE, F.M. and GOMES, L.C., 2008. Dams and the fish fauna of the Neotropical region: impacts and management related to diversity and fisheries. Brazilian Journal of Biology $=$ Revista Brasileira de Biologia, vol. 68, no. 4, suppl., pp. 1119-1132. http://dx.doi.org/10.1590/S151969842008000500019. PMid:19197482.
ALVES, C.B.M., VIEIRA, F., MAGALHÃES, A. and BRITO, M., 2007. Impacts of non-native fish species in Minas Gerais, Brazil: present situation and prospects. In: T.M. BERT, ed. Ecological and genetic implications of aquaculture activities. Dordrecht: Springer, pp. 291-314.

ANDERSON, M.J., GORLEY, R.N. and CLARKE, K.R., 2008. PERMANOVA + for PRIMER: guide to software and statistical methods. Plymouth: PRIMER-E. 274 p.

ARAÚJO-LIMA, C.A.R.M., AGOSTINHO, A.A. and FABRÉ, N.N., 1995. Trophic aspects of fish communities in Brazilian rivers and reservoirs. In: J.G. TUNDISI, C.E.M. BICUDO and T. MATSUMURA-TUNDISI, eds. Limnology in Brazil. Rio de Janeiro: Brazilian Academy of Sciences, pp. 105-136.

ASSIREU, A.T., ALCÂNTARA, E., NOVO, E.M.L.M., ROLAND, F., PACHECO, F.S., STECH, J.L. and LORENZZETTI, J.A., 2011. Hydro-physical processes at the plunge point: an analysis using satellite and in situ data. Hydrology and Earth System Sciences, vol. 15 , no. 12 , pp. $3689-3700$. http://dx.doi.org/10.5194/hess15-3689-2011.

BENEDiTO-CECILIO, E. and AGOSTINHO, A.A., 2000. Distribution, abundance and use of different environments by dominant ichthyofauna in the influence area of the Itaipu Reservoir. Acta Scientiarum: Biological Sciences, vol. 22, pp. 429-437.

CARVALHO, E.D. and SILVA, V.F.B., 2007. Aspectos ecológicos da ictiofauna e da produção pesqueira do reservatório de Jurumirim (Alto Paranapanema - São Paulo). In: R. HENRY, ed. Ecologia de reservatórios: estrutura, função e aspectos sociais. Botucatu: FUNDBIO, pp. 774-799.

CHAVEZ JUNIOR, P.S., 1988. An improved dark-object subtraction technique for atmospheric scattering correction of multispectral data. Remote Sensing of Environment, vol. 24, no. 3, pp. 459-479. http://dx.doi.org/10.1016/0034-4257(88)90019-3.

CLARKE, K.R. and WARWICK, R.M., 2001. Change in marine communities: an approach to statistical analysis and interpretation. 2nd ed. Plymouth: PRIMER-E.

COLWELL, R.K., 2009 [viewed 14 August 2014]. EstimateS, Version 8.2: statistical estimation of species richness and shared species from samples [online]. Connecticut: University of Connecticut. Software and user's guide. Available from: http:// viceroy.eeb.uconn.edu/estimates

GAO, X., ZENG, Y., WANG, J. and LIU, H., 2010. Immediate impacts of the second impoundment on fish communities in the Three Gorges Reservoir. Environmental Biology of Fishes, vol. 87, no. 2, pp. 163-173. http://dx.doi.org/10.1007/s10641-009-9577-1.

GEHRKE, P.C. and HARRIS, J.H., 2001. Regional-scale effects of flow regulation on lowland riverine fish communities in New South Wales, Australia. Regulated Rivers: Research and Management, vol. 17, no. 4-5, pp. 369-391. http://dx.doi.org/10.1002/rrr.648.

GEHRKE, P.C., GILLIGAN, D.M. and BARWICK, M., 2002. Changes in fish communities of the Shoalhaven river 20 years after construction of Tallowa dam, Australia. River Research and Applications, vol. 18, no. 3, pp. 265-286. http://dx.doi. org/10.1002/rra.669.

GIDO, K.B., SCHAEFER, J.F. and FALKE, J.A., 2009. Convergence of fish communities from the littoral zone of reservoirs. Freshwater Biology, vol. 54, no. 6, pp. 1163-1177. http://dx.doi.org/10.1111/j.1365-2427.2008.02162.x.

GOMES, L.C. and MIRANDA, L.E., 2001. Riverine characteristics dictate composition of fish assemblages and limit fisheries in 
reservoirs of the upper Paraná river basin. Regulated Rivers: Research and Management, vol. 17, no. 1, pp. 67-76. http:// dx.doi.org/10.1002/1099-1646(200101/02)17:1<67::AIDRRR615>3.0.CO;2-P

GRAÇA, W.J. and PAVANELLI, C.S., 2007. Peixes da planície de inundação do alto Rio Paraná e áreas adjacentes. Maringá: Editora da Universidade Estadual de Maringa. 241 p.

HARRINGTON JUNIOR, J.A., SCHIEBE, E.F.R. and NIX, J.F., 1992. Remote sensing of Lake Chicot, Arkansas: monitoring suspended sediments, turbidity and Secchi depth with Landsat MSS data. Remote Sensing of Environment, vol. 39, no. 1, pp. 15-27. http://dx.doi.org/10.1016/0034-4257(92)90137-9.

HEDGER, R.D., OLSEN, N.R.B., MALTHUS, T.J. and ATKINSON, P.M., 2002. Coupling remote sensing with computational fluid dynamics modeling to estimate lake chlorophyll- $a$ concentration. Remote Sensing of Environment, vol. 79, no. 1, pp. 116-122. http:// dx.doi.org/10.1016/S0034-4257(01)00244-9.

HUGHES, R.M. and HERLIHY, A.T., 2012. Patterns in catch per unit effort of native prey fish and alien piscivorous fish in 7 Pacific Northwest USA rivers. Fisheries, vol. 37, no. 5, pp. 201211. http://dx.doi.org/10.1080/03632415.2012.676833.

HUGHES, R.M., RINNE, J.N. and CALAMUSSO, B., 2005. Historical changes in large river fish assemblages of the Americas: a synthesis. In: J.N. RINNE, R.M. HUGHES and B. CALAMUSSO, eds. Historical changes in Large River Fish Assemblages of the Americas. Bethesda: American Fisheries Society, pp. 603-612.

IRZ, P., LAURENT, A., MESSAD, S., PRONIER, O. and ARGILLIER, C., 2002. Influence of site characteristics on fish community patterns in French reservoirs. Ecology Freshwater Fish, vol. 11, no. 2, pp. 123-136. http://dx.doi.org/10.1034/j.16000633.2002.00004.x

JENSEN, J.R., 2006. Remote sensing of the environment: an earth resource perspective. 2 nd ed. Englewood Cliffs: Prentice Hall.

LEGENDRE, L. and LEGENDRE, P., 1998. Numerical ecology: developments in environmental modelling. Amsterdam: Elsevier.

LEPRIEUR, F., BEAUCHARD, O., BLANCHET, S., OBERDORFF, T. and BROSSE, S., 2008. Fish invasions in the world's river systems: when natural processes are blurred by human activities. PLoS Biology, vol. 6, no. 2, pp. e28. http://dx.doi.org/10.1371/ journal.pbio.0060028. PMid:18254661.

LUIZ, T.F., 2010. Características biológicas do peixe amazônico Cichla piquiti (Cichlidae: Perciformes) introduzido no reservatório de Cachoeira Dourada no rio Paranaíba, Brasil. São Carlos: Universidade Federal do São Carlos. Masters Dissertation.

MACEDO, D.R., LIGEIRO, R., FERREIRA, W.R., JUNQUEIRA, N.T., SANCHES, B.O., SILVA, D.R.O., ALVES, C.B.M., HUGHES, R.M., KAUFMANN, P.R., POMPEU, P.S., SANTOS, G.B. and CALLISTO, M., 2012. Parâmetros biológicos e de habitats físicos para a avaliação de bacias no sudeste do Brasil. Ação Ambiental, vol. 13 , pp. $15-18$.

MAGURRAN, A.E., 2011. Biological diversity: frontiers in measurement and assessment. Oxford: Oxford University Press.

MANTEL, N., 1967. The detection of disease clustering and a generalized regression approach. Cancer Research, vol. 27, no. 2, pp. 209-220. PMid:6018555.

MCCUNE, B., GRACE, J.B. and URBAN, D.L., 2002. Analysis of ecological data. Gleneden Beach: MjM Software Design.
OBERDORFF, T. and HUGHES, R.M., 1992. Modification of an index of biotic integrity based on fish assemblages to characterize rivers of the Seine Basin, France. Hydrobiologia, vol. 228, no. 2, pp. 117-130. http://dx.doi.org/10.1007/BF00006200.

OLIVEIRA, E.F. and GOULART, E., 2000. Distribuição espacial de peixes em ambientes lênticos: interação de fatores. Acta Scientiarum, vol. 22, pp. 445-453.

OLIVEIRA, E.F., GOULART, E. and MINTE-VERA, C.V., 2003. Patterns of dominance and rarity of fish assemblages along spatial gradients in the Itaipu Reservoir, Paraná, Brazil. Acta Scientiarum, vol. 25, pp. 71-78.

OLIVEIRA, E.F., GOULART, E. and MINTE-VERA, C.V., 2004. Fish diversity along spatial gradients in the Itaipu reservoir, Paraná, Brazil. Brazilian Journal of Biology = Revista Brasileira de Biologia, vol. 64, no. 3A, pp. 447-458. http://dx.doi.org/10.1590/ S1519-69842004000300008. PMid:15622842.

OLIVEIRA, E.F., MINTE-VERA, C.V. and GOULART, E., 2005. Structure of fish assemblages along spatial gradients in a deep subtropical reservoir (Itaipu Reservoir, Brazil-Paraguay border). Environmental Biology of Fishes, vol. 72, no. 3, pp. 283-304. http://dx.doi.org/10.1007/s10641-004-2582-5.

PELICICE, F.M. and AGOSTINHO, A.A., 2009. Fish fauna destruction after the introduction of a non-native predator (Cichla kelberi) in a Neotropical reservoir. Biological Invasions, vol. 11, no. 8, pp. 1789-1801. http://dx.doi.org/10.1007/s10530-008-9358-3.

POFF, N.L., OLDEN, J.D., MERRITT, D.M. and PEPIN, D.M., 2007. Homogenization of regional river dynamics by dams and global biodiversity implications. Proceedings of the National Academy of Sciences of the United States of America, vol. 104, no. 14, pp. 5732-5737. http://dx.doi.org/10.1073/pnas.0609812104. PMid:17360379.

PRCHALOVÁ, M., KUBEČKA, J., ČECH, M., FROUZOVÁ, J., DRAŠTIIK, V., HOHAUSOVÁ, E., JŮZA, T., KRATOCHVÍL, M., MATĚNA, J., PETERKA, J., ŘIIHA, M., TUŠER, M. and VAŠEK, M., 2009. The effect of depth, distance from dam and habitat on spatial distribution of fish in an artificial reservoir. Ecology Freshwater Fish, vol. 18, no. 2, pp. 247-260. http:// dx.doi.org/10.1111/j.1600-0633.2008.00342.x.

PRCHALOVÁ, M., KUBEČKA, J., VAŠEK, M., PETERKA, J., SED', A.J., JŮZA, T., ŘIIHA, M., JAROLÍM, O., TUŠER, M., KRATOCHVÍL, M., ČECH, M., DRAŠTÍK, V., FROUZOVÁ, J. and HOHAUSOVÁ, E., 2008. Distribution patterns of fishes in a canyon-shaped reservoir. Journal of Fish Biology, vol. 73, no. 1, pp. 54-78. http://dx.doi.org/10.1111/j.1095-8649.2008.01906.x.

R CORE TEAM, 2012 [viewed 14 August 2014]. R: a language and environment for statistical computing [online]. Vienna: $\mathrm{R}$ Foundation for Statistical Computing. Available from: http:// www.R-project.org

REGIER, H.A., HUGHES, R.M. and GANNON, J.E., 2013. The lake sturgeon as survivor and integrative indicator of changes in stressed aquatic ecosystems in the Laurentian Basin. In: D. DEMPSEY and N. AUER, eds. The Great Lake Sturgeon. East Lansing: Michigan State University Press, pp. 27-57.

RÊGO, A.C.L., 2008. Composição, abundância e dinâmica reprodutiva e alimentar de populações de peixes de um reservatório recémformado (UHE Capim Branco I/MG). Uberlândia: Universidade Federal de Uberlândia. Masters Dissertation. 
STATSOFT, 2007 [viewed 14 August 2014]. STATISTICA: data analysis software system. Version 7.1 [online]. Cary. Available from: www.statsoft.com

STEVENS, D.L. Jr. and OLSEN, A.R., 2004. Spatially balanced sampling of natural resources. Journal of the American Statistical Association, vol. 99, no. 465, pp. 262-278. http://dx.doi. org/10.1198/016214504000000250.

TERRA, B.D. and ARAÚJO, F.G., 2011. A preliminary fish assemblage index for a transitional river-reservoir system in southeastern Brazil. Ecological Indicators, vol. 11, no. 3, pp. 874-881. http://dx.doi.org/10.1016/j.ecolind.2010.11.006.

TERRA, B.D.F., SANTOS, A.B.I. and ARAÚJO, F.G., 2010. Fish assemblage in a dammed tropical river: an analysis along the longitudinal and temporal gradients from river to reservoir.
Neotropical Ichthyology, vol. 8, no. 3, pp. 599-606. http://dx.doi. org/10.1590/S1679-62252010000300004.

THORNTON, K.W., 1990. Perspectives on reservoir limnology. In: K.W. THORNTON, B.L. KIMMEL and F.E. PAYNE, eds. Reservoir limnology: ecological perspectives. Somerset: John Wiley \& Sons, pp. 1-15.

VONO, V., 2002. Efeitos da implantação de duas barragens sobre a estrutura da comunidade de peixes do rio Araguari (bacia do Alto Paraná, $M G$ ). Belo Horizonte: Universidade Federal de Minas Gerais. PhD Thesis.

WETZEL, R.G., 2001. Limnology: lake and river ecosystems. 3rd ed. San Diego: Academic Press. 998 p.

ZAR, J.H., 2009. Biostatistical analysis. 5th ed. Englewood Cliffs: Prentice Hall. 960 p. 
Appendix A. Fish species collected from Nova Ponte Reservoir.

\begin{tabular}{|c|c|c|}
\hline & & Species \\
\hline \multirow[t]{19}{*}{ Characiformes } & Bryconidae & Salminus hilarii Valenciennes, 1850 \\
\hline & Anostomidae & Leporellus vittatus (Valenciennes, 1850) \\
\hline & & Leporinus amblyrhynchus Garavello and Britski, 1987 \\
\hline & & Leporinus friderici (Bloch, 1794) \\
\hline & & Leporinus obtusidens (Valenciennes, 1837) \\
\hline & & Leporinus octofasciatus Steindachner, 1915 \\
\hline & & Schizodon nasutus Kner, 1858 \\
\hline & Characidae & Astyanax altiparanae Garutti and Britski, 2000 \\
\hline & & Astyanax gr. fasciatus (Cuvier, 1829) \\
\hline & & Astyanax schubarti Britski, 1964 \\
\hline & & Galeocharax knerii (Steindachner, 1879) \\
\hline & & Moenkhausia costae (Steindachner, 1907) \\
\hline & Curimatidae & Cyphocharax modestus (Fernández-Yépez, 1948) \\
\hline & & Steindachnerina insculpta (Fernandez-Yepez, 1948) \\
\hline & Erythrinidae & Hoplias intermedius Oyakawa and Mattox, 2009 \\
\hline & & Hoplias gr. malabaricus (Bloch, 1794) \\
\hline & Prochilodontidae & Prochilodus lineatus (Valenciennes, 1836) \\
\hline & Serrasalmidae & Metynnis gr. lippincottianus (Cope, 1870) \\
\hline & & Pygocentrus nattereri Kner, 1858 \\
\hline \multirow[t]{5}{*}{ Perciformes } & Cichlidae & Cichla piquiti Kullander and Ferreira, 2006 \\
\hline & & Cichlasoma paranaense Kullander, 1983 \\
\hline & & Geophagus brasiliensis (Quoy and Gaimard, 1824) \\
\hline & & Oreochromis niloticus (Linnaeus, 1758) \\
\hline & & Tilapia rendalli (Boulenger, 1897) \\
\hline \multirow[t]{5}{*}{ Siluriformes } & Auchenipteridae & Trachelyopterus galeatus (Linnaeus, 1766) \\
\hline & Heptapteridae & Pimelodella gracilis (Valenciennes, 1835) \\
\hline & Loricariidae & Hypostomus sp. \\
\hline & Pimelodidae & Iheringichthys labrosus (Lütken, 1874) \\
\hline & & Pimelodus cf. maculatus Lacepède, 1803 \\
\hline
\end{tabular}

